\title{
From forestry and heavy industry to a vibrant knowledge-based economy
}

Written by: Christophe André

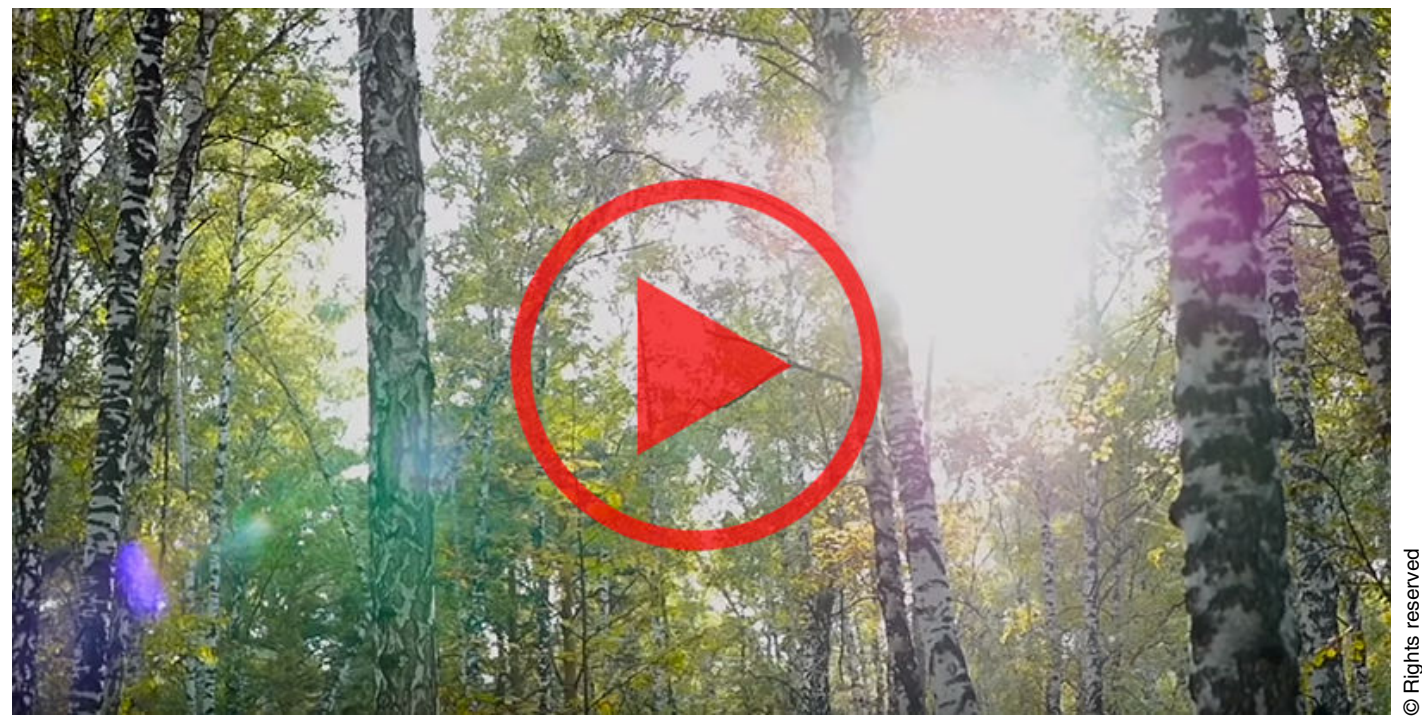

Video: Happy 50th anniversary, Finland at the OECD! https://oe.cd/obs/2zl

On a cold, dark Helsinki winter's day in 2014, I was waiting for OECD Secretary- General Angel Gurría and my other colleagues in a black limousine in front of the austere parliament building. The scene could have come out of a John le Carré thriller. It was late in the day. The OECD delegation I was waiting for was meeting Alexander Stubb, then the minister for European affairs and foreign trade. One of Finland's most europhile and techsavvy statesmen, Mr Stubb soon became prime minister. How things had changed in $\mathbf{5 0}$ years.

In 1969, when Finland became an OECD member country, Cold War tensions were still running high. The decade had started with the Cuban missile crisis and building of the Berlin Wall. Finland was a small country squeezed between the Soviet and US superpowers. President Urho Kekkonen, who held office for a 
quarter of a century (1956-81), was striving to keep a delicate balance between East and West.

Finland's road to prosperity and integration with the West has been long and bumpy. The first OECD Economic Survey of Finland, published in 1969, noted that "the heavy weight of agriculture both in terms of output and employment is still

Finland's road to prosperity and integration with the West has been long and bumpy an important feature of the Finnish economy." At that time, less than $65 \%$ of Finns lived in cities compared to $80 \%$ of Swedes. Agriculture still employed a quarter of the Finnish workforce. Industry accounted for more than a third of employment, dominated by the wood and pulp and paper sectors, as well as metal industries, such as shipbuilding and lifting, transport and electrical equipment. Finland's income per capita was almost 30\% lower than in Sweden, to where many Finns were emigrating to find better jobs.

During the 1970s and 1980s, Finland rapidly caught up with Germany and Sweden in terms of income per capita, with the gap shrinking to less than 10\% (see chart). But in the early 1990s, Finland went through a deep recession: GDP contracted by 10\% between 1990 and 1993. The collapse of the Soviet Union had disrupted trade links. The Finnish economy was damaged as well by a severe banking crisis caused by poor supervision following financial market deregulation in the late 1980s. Finland and other Nordic countries buttressed their financial systems in the following years. Alas, many other countries around the world failed to learn from the Nordic experience, and let financial imbalances accumulate until they triggered the global financial crisis in 2008. 


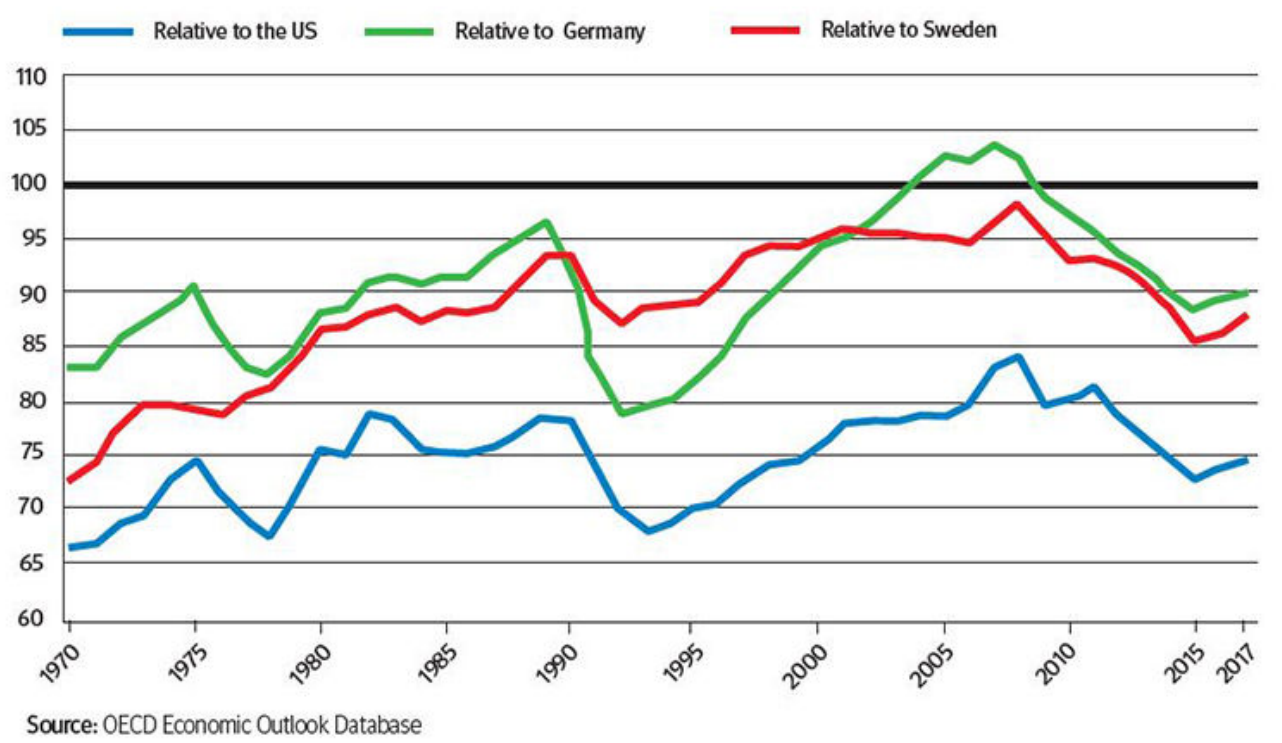

The 1990s crisis was painful. The unemployment rate peaked at nearly $18 \%$ in 1994. But Finland showed its resilience-its sisu, as the Finns say. The economy rebounded and became increasingly knowledge-based, as illustrated by the spectacular success of Nokia, which in the 1990s became one of the world's leading brands in mobile phone handsets. Finland joined the European Union in 1995, which supported economic reforms and boosted trade. When the global financial crisis hit in 2008, Finland's output per capita had caught up with Germany's and Sweden's. But, as in the 1990s, the crisis hit hard. The effects of the global economic downturn were compounded by the collapse of Nokia's mobile phone business, a sharp fall in demand for paper and a recession in Russia. It took 10 years for Finland's GDP to get back to its pre-crisis level. But economic growth and employment have rebounded over the past three years and optimism has returned.

What has OECD membership brought to Finland? Policy advisers and economists point to the political importance of joining a club of western democracies 50 years ago, leading to closer international integration and convergence. They value the OECD's contribution to Finland's public policy debate in a widening range of areas, with comparable data, benchmarking, research-based evidence and comparative analysis. The OECD provides a valuable "outsider's" view on policies and fosters continual exchanges of views with member countries' analysts and policymakers. As an OECD economist, I greatly value the very open, constructive and stimulating debates I have with my Finnish counterparts. 
They are rightly proud of Finland's successes and of what their country brings to fellow OECD members. Finland offers a wide range of bestpractice examples, from education to innovation and inclusive growth. It is among the best performers in PISA-the OECD's worldwide education test among 15-yearolds. It is an innovation leader according to the European Innovation Scoreboard. It enjoys a level of income inequality that is among the lowest in the OECD. Finland is also one of the most gender-equal countries in the world. When I started working on my first OECD Economic Survey of Finland in 2011, Tarja Halonen was the president of Finland and Mari Kiviniemi, who was later to become a deputy secretary-general at the OECD, was prime minister. But having two women in the country's top jobs was not surprising for the first country in the world to elect women as members of parliament, in 1907 (Finland was, then, an autonomous Grand Duchy, part of Russia).

Today, Finland faces new challenges, not least having to cope with a rapidly ageing population and rising global economic and political uncertainties. During what has been nearly a decade on the Finland desk at the OECD, I have been impressed by how Finnish policymakers and economic stakeholders more broadly address challenges in a very rational and pragmatic way, as well as their ability to build consensus on decisive issues. This gives me confidence that Finland will achieve as much over the next 50 years as it has since 1969, and that it will continue to inspire its OECD peers and others beyond in the pursuit of better policies for better lives.

COECD Observer, January 2019

\section{References}

OECD Economic Surveys: Finland 2018 http://dx.doi.org/10.1787/eco_surveysfin-2018-en

European Innovation Scoreboard 2018 https://ec.europa.eu/growth/industry/ innovation/facts-figures/scoreboards_en 